\title{
Case of late-onset Sandhoff disease due to a novel mutation in the HEXB gene
}

Angela R. Sung, MD, Paolo Moretti, MD, and Aziz Shaibani, MD

Neurol Genet 2018;4:e260. doi:10.1212/NXG.0000000000000260

Correspondence

Dr. Shaibani

ataher@aol.com

Sandhoff disease is one of a group of autosomal recessive conditions known as the GM2 gangliosidoses. Normal breakdown of GM2 gangliosides is performed by the enzyme $\beta$-hexosaminidase A. This enzyme consists of 2 subunits ( $\alpha$ and $\beta$ ), which are encoded by the HEXA and HEXB genes, respectively. Mutations in either of these genes result in buildup of the GM2 gangliosides, with HEXA mutations producing a phenotype of Tay-Sachs disease and HEXB mutations causing Sandhoff disease.

The classic form of Sandhoff disease presents in infancy with symptom onset between ages 2 and 9 months. Symptoms include progressive weakness, intellectual disability, vision and hearing impairment, exaggerated startle response, seizures, and death usually before age 3 . Lateonset forms of Sandhoff disease have been described but are much rarer. Adult-onset cases can present with a wide spectrum of symptoms, including spinocerebellar ataxia, motor neuron disease, sensorimotor neuropathy, tremor, dystonia, and psychosis. ${ }^{1}$ Specifically, in reviewing cases with the motor neuron disease phenotype, most reports describe predominant lower motor neuron features, with few cases showing both upper and lower motor neuron findings similar to amyotrophic lateral sclerosis. ${ }^{2,3}$ More recent reports have identified an increasing number of novel sequence variants (often compound heterozygous point mutations) that are associated with the motor neuron disease phenotype, ${ }^{4,5}$ although the mechanism by which these variants produce this specific phenotype is not well understood.

\section{Case presentation}

A 40-year-old woman was referred for evaluation of slowly progressive weakness of the lower extremities over the course of 3 years. She reported weakness affecting both legs, difficulty standing from a chair, poor balance, and twitching in her thigh muscles. Additional symptoms included anxiety, mood fluctuations, decreased concentration, generalized fatigue, and poor sleep. She denied numbness, pain, arm weakness, difficulty with breathing, speaking, or swallowing.

On physical examination, she had mild weakness in the hip flexors, knee flexors, and knee extensors, with full strength in all other muscle groups. There was mild atrophy of the knee extensors with rare fasciculations. Deep tendon reflexes were reduced at the knees, but intact elsewhere. Tandem gait was slightly impaired. The rest of the neurologic examination was within normal limits.

Brain MRI revealed mild cerebral and cerebellar atrophy with preferential involvement of the superior vermis. Lumbar spine MRI was significant for mild degenerative changes at the L3-L4 levels and bilateral neural foraminal stenosis at the L5-S1 levels. EMG and nerve conduction

From the Department of Neurology (A.R.S.), Baylor College of Medicine; Neurology Care Line (P.M.), Michael E. DeBakey Veterans Affairs Medical Center; and Nerve and Muscle Center of Texas (A.S.), Houston, TX.

Funding information and disclosures are provided at the end of the article. Full disclosure form information provided by the authors is available with the full text of this article at Neurology.org/NG.

The Article Processing Charge was funded by the authors.

This is an open access article distributed under the terms of the Creative Commons Attribution-NonCommercial-NoDerivatives License 4.0 (CC BY-NC-ND), which permits downloading and sharing the work provided it is properly cited. The work cannot be changed in any way or used commercially without permission from the journal. 
Figure G473S conservation across species

\begin{tabular}{llllll|l|llllll} 
Hs & P & L & D & F & G \\
Mm & P & L & N & F & E & G & T & Q & K & Q & K & 478 \\
Dr & P & Q & N & F & N & S & E & K & Q & K & 457 \\
Dm & L & K & S & I & A & T & D & A & Q & K & 464 \\
Ce & P & T & N & F & N & D & Y & E & H & H & 520 \\
G & & V & A & Q & K & 466
\end{tabular}

Multiple protein alignment highlighting the evolutionary conservation of glycine 473 in the human hexosaminidase subunit beta (HEXB) amino acid sequence. Labels: $\mathrm{Hs}=$ Homo sapiens; $\mathrm{Mm}=$ Mus musculus; $\mathrm{Dr}=$ Danio rerio; $\mathrm{Dm}=$ Drosophila melanogaster $; \mathrm{Ce}=$ Caenorhabditis elegans. The numbers on the right side of each sequence correspond to the last amino acid depicted.

studies was normal except for neurogenic units in the knee extensors and hip flexors. The creatine kinase level was normal.

The pure motor nature of the findings and the EMG results suggested a chronic form of lower motor neuron disease, and the MRI findings did not adequately explain her symptoms. The picture was not typical of any of the common lower motor neuron diseases. Because there is no inclusive panel for genetic motor neuron diseases and the affected gene could not be pinpointed clinically, whole-exome sequencing (WES) was performed for further evaluation. WES revealed a compound heterozygous mutation in the HEXB gene on chromosome 5 (c.298delC pathogenic variant and G473S likely pathogenic variant). Subsequent hexosaminidase enzymatic testing revealed reduced total hexosaminidase activity in leukocytes (14\% that of normal controls), consistent with a GM2 gangliosidosis. In addition, there was a high ratio of hexosaminidase A to B activity (79\%), supporting a diagnosis of Sandhoff disease.

\section{Discussion}

This case describes 2 new sequence variants found in a patient with clinical symptoms of Sandhoff disease. The population frequency of these 2 sequence variants was investigated using the Genome Aggregation Database (gnomAD), which aggregates data on 123,136 exomes and 15,495 genomes from unrelated individuals. ${ }^{6}$ The c.298delC variant in HEXB is predicted to result in loss of protein function and is absent from the gnom $\mathrm{AD}$, indicating a very rare, likely pathogenic variant. The G473S variant in $H E X B$ has been observed only once in the heterozygous state in the gnomAD. The amino acid position 473 is highly conserved across evolution, with an invariant glycine residue present from Caenorhabditis elegans and Drosophila melanogaster to various species of vertebrates (figure). ${ }^{7}$ The presence of these 2 sequence variants in the compound heterozygous state, combined with the enzymatic assay showing decreased hexosaminidase activity, implies that these sequence variants are pathogenic and are responsible for the loss of enzymatic activity.

Late-onset Sandhoff disease is rare but should remain a diagnostic consideration in adults presenting with slowly progressive lower motor neuron disease, and discovery of new pathogenic sequence variants such as the ones discussed in this case will help further understanding of this disease and facilitate diagnosis in future patients.

\section{Author contributions}

A.R. Sung reviewed the literature, drafted the initial manuscript, and made multiple subsequent revisions. P. Moretti investigated the 2 sequence variants discussed in this manuscript in genetic databases and interpreted the data. A. Shaibani collected clinical data during clinical consultation with the patient and performed testing that led to the discovery of the discussed sequence variants; he also made multiple revisions to the manuscript.

\section{Study funding}

No targeted funding reported.

\section{Disclosure}

A.R. Sung reports no disclosures. P. Moretti has received research support from the New Jersey Commission on Brain Injury Research and the Department of Veterans Affairs. A. Shaibani receives publishing royalties from Oxford University Press. Full disclosure form information provided by the authors is available with the full text of this article at Neurology.org/NG.

Received February 28, 2018. Accepted in final form May 8, 2018.

\section{References}

1. Johnson WG. The clinical spectrum of hexosaminidase deficiency diseases. Neurology 1981;31:1453-1456.

2. Delnooz CCS, Lefeber DJ, Langemeijer SMC, et al. New cases of adult-onset Sandhoff disease with a cerebellar or lower motor neuron phenotype. J Neurol Neurosurg Psychiatry 2010;81:968-972.

3. Scarpelli M, Tomelleri G, Bertolasi L, Salviati A. Natural history of motor neuron disease in adult onset GM2-gangiosidosis: a case report with 25 years of follow up. Mol Genet Metab Rep 2014;1:269-272.

4. Yoshizawa T, Kohno Y, Nissato S, Shoji S. Compound heterozygosity with two novel mutations in the HEXB gene produces adult Sandhoff disease presenting as a motor neuron disease phenotype. J Neurol Sci 2002;195:129-138.

5. Banerjee P, Boyers MJ, Berry-Kravis E, Dawson G. Preferential beta-hexosaminidase (Hex) A (alpha beta) formation in the absence of beta-Hex B (beta beta) due to heterozygous point mutations present in beta-Hex beta-chain alleles of a motor neuron disease patient. J Biol Chem 1994;269:4819-4826.

6. Lek M, Karczewski KJ, Minikel EV, et al. Analysis of protein-coding genetic variation in 60,706 humans. Nature 2016;536:285-291.

7. MARRVEL [Database online]. Houston: Baylor College of Medicine; 2017. Available at: marrvel.org/. Accessed May 9, 2007. 


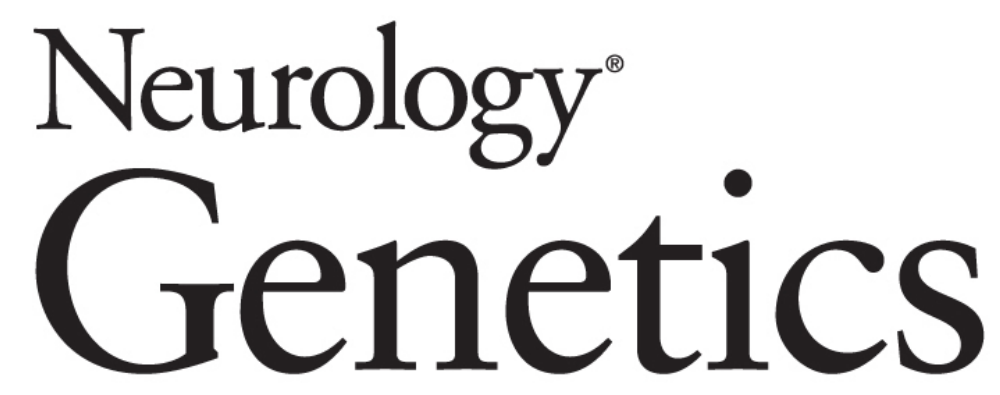

Case of late-onset Sandhoff disease due to a novel mutation in the HEXB gene Angela R. Sung, Paolo Moretti and Aziz Shaibani

Neurol Genet 2018;4;

DOI 10.1212/NXG.0000000000000260

This information is current as of July 30, 2018

\section{Updated Information \&} Services

References

Subspecialty Collections

Permissions \& Licensing

Reprints including high resolution figures, can be found at: http://ng.neurology.org/content/4/4/e260.full.html

This article cites 6 articles, 2 of which you can access for free at: http://ng.neurology.org/content/4/4/e260.full.html\#\#ref-list-1

This article, along with others on similar topics, appears in the following collection(s):

\section{All Genetics}

http://ng.neurology.org//cgi/collection/all_genetics

All Neuromuscular Disease

http://ng.neurology.org//cgi/collection/all_neuromuscular_disease

Information about reproducing this article in parts (figures,tables) or in its entirety can be found online at:

http://ng.neurology.org/misc/about.xhtml\#permissions

Information about ordering reprints can be found online: http://ng.neurology.org/misc/addir.xhtml\#reprintsus

Neurol Genet is an official journal of the American Academy of Neurology. Published since April 2015, it is an open-access, online-only, continuous publication journal. Copyright Copyright $\odot 2018$ The Author(s). Published by Wolters Kluwer Health, Inc. on behalf of the American Academy of Neurology.. All rights reserved. Online ISSN: 2376-7839.

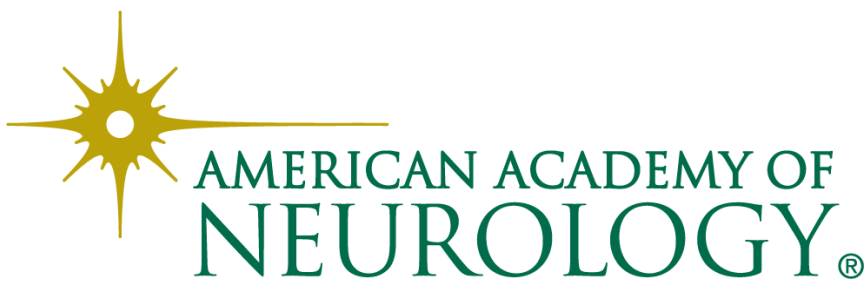

